\title{
Anak sebagai Penyalahguna Narkotika dalam Perspektif Viktimologi
}

\author{
Dimas Pangestu; Hafrida
}

Fakultas Hukum Universitas Jambi

Author's email correapondence: dimasdepangestu@gmail.com:

\section{ABSTRAK}

Artikel ini menganalisis pelaku penyalah guna narkotika anak dalam perspektif victimologi sehingga tujuan artikel ini untuk mendapatkan kejelasan, mengkaji dan menganalisis mengenai kebijakan hukum pidana mengenai viktimisasi anak penyalah guna narkotika.Penelitian ini merupakan penelitian normatif yaitu penelitian yang dilakukan secara kepustakaan dengan mendeskripsikan hukum positif, mensistematisasi, menginterprestasikan, menilai, dan menganalisis hukum positif tersebut.Hasil penelitian pelaku anak sebagai penyalah guna narkotika menunjukan pemidanan berupa pidana penjara masih dominan dibandingkan sanksi untuk direhabilitasi.Hal ini menunjukan bahwa anak sebagai penyalah guna narkotika dalam perspektif hukum pidana saat ini masih dipandang senagai kriminal atau pelaku tindak pidana. Hal inilah yang menarik untuk dikaji anak sebagai penyalah guna sebaiknya tidak dikatagorikan sebgai pelaku tindak pidana tetapi lebih dipandang sebagai korban dari tindak pidana narkotika dan sebagi korban ketidakmampuan negara dalam penangguangi tindak pidana narkotika di Indonesia.
Kata Kunci: Viktimologi; Anak; Penyalah Guna; Narkotika.

\section{ARTICLE HISTORY}

Submission: 2020-04-16

Accepted: 2020-10-09

Publish: 2020-10-10

KEYWORDS: Victimology; Child; Misuse; Narcotics.

ABSTRACT
This article analyzes child narcotics abusers from a
victimology perspective so that the purpose of this article
is to get clarity, study and analyze the criminal law policy
regarding the victimization of child abusers of narcotics.
This research is a normative study, namely research
conducted in a literature describing positive law,
systematizing, interpreting, assessing, and analyzing the
positive law. The research results of child offenders as
narcotics abusers show that imprisonment is still
dominant compared to sanctions to be rehabilitated.This
is what is interesting to examine as children as abusers
should not be categorized as perpetrators of criminal acts
but rather as victims of narcotics crimes and as victims.
the inability of the state to tackle narcotics crime in
Indonesia.

\section{ABSTRACT}

This article analyzes child narcotics abusers from a is to get clarity, study and analyze the criminal law policy regarding the victimization of child abusers of narcotics. This research is a normative study, namely research conducted in a literature describing positive law, systematizing, interpreting, assessing, and analyzing the positive law. The research results of child offenders as narcotics abusers show that imprisonment is still dominant compared to sanctions to be rehabilitated.This is what is interesting to examine as children as abusers should not be categorized as perpetrators of criminal acts but rather as victims of narcotics crimes and as victims. Indonesia. 


\section{A. PENDAHULUAN}

Penyebaran narkotika pada kalangan anak-anak sudah sampai pada tahap yang sangat sulit dikendalikan khususnya anak sebagai penyalah guna narkotika, kenyataan tersebut sangat mengkhawatirkan karena anak-anak adalah generasi penerus bangsa di masa yang akan datang. Anak-anak memerlukan pembinaan dan perlindungan khusus. Anak pada umumnya memiliki rasa keingintahuan yang besar, sehingga informasi-informasi atau sesuatu hal yang baru pantas dicoba tanpa menyadari akibat dari hal baru tersebut mengarah kepada kebaikan atau sebaliknya.

Penyalah guna dalam teori victimology dianggap sebagai korban karena menanggung kerugian meteri dan sakit adiksi, namun oleh Undang-Undang hal tersebut dikriminalkan sebagai bentuk pencegahan terjadinya penyalah guna. ${ }^{45}$

"Pola penyamarataan antara pengguna narkotika dengan pihak yang melakukan perdagangan gelap narkotika akan semakin memperburuk masa depan korban perederan gelap narkotika dam berpotensi melanggar hak mereka sebagai manusia. Sebagaimana dikemukakan sebelumnya, korban pengguna narkotika ini terbesar pada usia remaja dan anakanak." 46

Anak sebagai penyalah guna narkotika, hanyalah korban. Sehingga tidak sepatutnya, negara memberikan hukuman dengan memandang sama antara anak penyalah guna dengan penjahat dewasa yang sesungguhnya. Sebagai korban maka anak sebagai penyalah guna narkotika wajib mendapatkan perlindungan. Perlindungan anak merupakan usaha yang dilakukan untuk menciptakan kondisi agar setiap anak dapat melaksanakan hak dan kewajibannya demi perkembangan dan pertumbuhan anak secara wajar, baik fisik, mental, dan sosial. ${ }^{47}$

Perkembangan penyalahgunaan narkotika semakin hari semakin meningkat dan pemerintah telah menerbitkan aturan yang mengatur tentang penanganan pelaku tindak pidana penayalah guna narkotika yaitu Undang-Undang Republik Indonesia Nomor 35 Tahun 2009 Tentang Narkotika. Sedangkan Anak yang menjadi pelaku tindak pidana atau kejahatan diatur dalam Undang-Undang Republik Indonesia Nomor 11 Tahun 2012 Tentang Sistem Peradilan Pidana Anak, sedangkan anak sebagi korban diatur dalam Undang-Undang Republik Indonesia Nomor 35 Tahun 2014 Tentang perubahan Undang-Undang Republik Indonesia Nomor 23 Tahun 2002 Tentang Perlindungan Anak. Oleh karena itu setiap tindak pidana yang dilakukan oleh anak diselesaikan melalui peradilan yang mana proses penyelesaiannya menggunakan mekanisme yang berbeda dari pengadilan pada umumnya.

Berdasarkan Pasal 1 angka 15 Undang-Undang Nomor 35 Tahun 2009 Tentang Narkotika menyebutkan "penyalah guna narkotika adalah orang yang

1 Anang Iskandar, Penegakan Hukum Narkotika Rehabilitatif Terhadap Penyalah Gunadan Pecandu, Represif terhadap Pengedar, Elex Media Komputindo, Jakarta, 2019, hlm. 53-54.

2 Hafrida, "Kebijakan Hukum Pidana Terhadap Pengguna Narkotika Sebagai Korban Bukan Pelaku Tindak Pidana : Studi Lapangan Daerah Jambi". Padjadjaran Jurnal Ilmu Hukum. Volume 6 Nomor 2. 2016, hal. 186. DOI: https:// doi.org/ 10.22304/ pjih.v3n1.a10. Retrieved from http:// jurnal.unpad.ac.id/pjih/article/view/9337.

3 Maidin Gultom, Perlindungan Hukum Terhadap Anak - Dalam Sistem Peradilan Pidana Anak di Indonesia, Rafika Aditama, Bandung, 2014, hlm.40 
menggunakan narkotika tanpa hak atau melawan hukum". Penyalah guna narkotika dapat diancam dengan Pasal 127 Undang-Undang Nomor 35 Tahun 2009 Tentang Narkotika, sebagai berikut:

(1) Setiap Penyalah Guna:

a. Narkotika Golongan I bagi diri sendiri dipidana dengan pidana penjara paling lama 4 (empat) tahun;

b. Narkotika Golongan II bagi diri sendiri dipidana dengan pidana penjara paling lama 2 (dua) tahun; dan

c. Narkotika Golongan III bagi diri sendiri dipidana dengan pidana penjara paling lama 1 (satu) tahun

(2) Dalam memutus perkara sebagaimana dimaksud pada ayat (1), hakim wajib memperhatikan ketentuan sebagaimana dimaksud dalam Pasal 54, Pasal 55, dan Pasal 103.

(3) Dalam hal Penyalah Guna sebagaimana dimaksud pada ayat (1) dapat dibuktikan atau terbukti sebagai korban penyalahgunaan Narkotika, Penyalah Guna tersebut wajib menjalani rehabilitasi medis dan rehabilitasi sosial.

Pasal 54 Undang-Undang Nomor 35 Tahun 2009 Tentang Narkotika menyebutkan "pencandu narkotika dan korban penyalah guna narkotika wajib menjalani rehabilitasi medis dan rehabilitasi sosial". Berdasarkan penjelasam pasal tersebut yanng dimaksud dengan korban penyalahgunaan narkotika adalah "seseorang yang tidak sengaja menggunakan narkotika karena dibujuk, diperdaya, ditipu, dipaksa, dan/atau diancam untuk menggunakan narkotika." Dapat dikatakan bahwa penyalah guna narkotika merupakan korban yang perlu pertolongan berupa rehabilitasi medis dan rehabilitasi sosial.

Kata setiap penyalah guna dalam pasal tersebut, mengartikan bahwa penyalah guna narkotika juga mencakup anak sebgai penyalah guna narkotika. Maka anak sebagai penyalah guna narkotika dapat dikenakan Undang-Undang Nomor 35 Tahun 2009 Tentang Narkotika. Namun dalam proses peradilannya anak harus menggunakan Undang-Undang Sistem Peradilan Pidana Anak sebagai ketentuan khusus yang diterapkan terhadap anak. Hal ini sebagai kosekuensi adalnya asas lex specialis derogat lex generalis. 48

"Dalam rangka penegakan hukum kepada pelaku tindak pidana harus dikenakan suatu akibat hukum, yang erat kaitannya dengan masalah pemidanaan.Hal tersebut berkaitan dengan dengan tujuan dari penegakan hukum yang hendak dicapai yaitu pemenuhan rasa keadilan dan pencapaian kepastian hukum.Dengan demikian, pemahana tentang tujuan dari pemidanaan hal ini penting untuk mengetahui maksud ditegaknya hukum itu.Sifat pemidanaan ini bukanlah semata-mata hanya bersifat punitif (menghukum) maupun mencari-cari kesalahn anak, tetapi unutuk memperbaiki anak dengan menghindarkannya dari perbuatan-perbuatan yang asosial." 49

48 Koesno Adi, Diversi Tindak Pidana Narkotika Anak, Setara Pess, Semarang, 2014, hlm. 23.

49 Harrys Pratama Teguh, Teori dan Praktek Perlindungan Anak dalam Hukum Pidana, Andi Offset, Jakarta, 2018, hlm. 42 
Menurut sistem Undang-Undang Perlindungan Anak, penjatuhan sanksi yang tepat untuk kepentingan anak dilaksanakan melalui upaya rehabilitasi. ${ }^{50}$ Yang tercantum pada Pasal 59 jo. Pasa 64 Undang-Undang Nomor 35 Tahun 2014 Tentang perubahan Undang-Undang Republik Indonesia Nomor 23 Tahun 2002 Tentang Perlindungan Anak.Hal tersebut sejalan dengan upaya pemberian rehabilitasi terhadap penyalah guna narkotika sesuai dengan Undang-Undang Nomor 35 Tahun 2009 Tentang Narkotika.Namun karena penyalah guna narkotika merupakan kejahatan tanpa korban, yang menurut ilmu viktimologi penyalah guna yang dibedakan secara tipologis termasuk mutual victimization.Maka untuk menentukan viktimisasi juga harus dilihat faktor yang menyebabkan seorang anak melakukan kejahatan.Walaupun anak dapat menentukan sendiri langkah perbuatannya berdasarkan fikiran, perasaan dan kehendaknya, tetapi disekitarnya dapat mempengaruhi perilakunya.

Untuk menentukan viktimisasi anak penyalah guna narkotika dilakukan dengan sistem peradilan pidana khusus bagi anak. Undang-Undang Nomor 11 Tahun 2012 Tentang Sistem Peradilan Pidana Anak sebagai sistem peradilan pidana khusus yang diberlakukan bagi anak, pada Pasal 2 menyebutkan bahwa sistem peradilan anak dilaksanakan berdasarkan :

1. Pelindugan atas hak-hak Anak;

2. Keadilan;

3. Nondiskriminasi;

4. Kepentingan terbaik bagi Anak;

5. Penghargaan terhadap pendapa Anak;

6. Kelangsungan hidup dan tumbuh kembang Anak;

7. Pembinaan dan pembimbingan Anak;

8. Proporsional;

9. Perampasan kemerdekaan dan pemidanna sebagai upaya terakhir; dan

10. Penghindaran pembalasan.

Dengan memperhatikan hal-hal tersebut, anak penyalah guna narkotika tidak seharusnya dikenakan pidana penjara yang berarti anak disamakan dengan orang dewasa. Untuk menjauhkan anak dari upaya perampasan kemerdekaan dan pembalasan, pada Pasal 5 Undang-Undangan Sistem Peradilan Pidana Anak wajib mengutamakan pendekatan keadilan restoratif.

"Keadilan restoratif merupakan suatu proses diversi yaitu semua pihak yang terkait dalam suatu tindak pidana tertentu bersama-sama mengatasi masalah serta menciptakan suatu kewajiban untuk membuat segala sesuatunya menjadi lebih baik dengan melibatkan korban, anak, masyarakat dan pihak terkait untuk mencari solusi yang terbaik bagi anak tanpa ada unsur pembalasan." 51

50 Ibid, hlm.42

51 Dheny Wahyudi, "Perlindungan Terhadap Anak Yang Berhadapan Dengan Hukum Melalui Pendekatan Restorative Justice. "Jurnal Ilmu Hukum Jambi, vol. 6, Nomor 1, 1 Feb. 2015. Retrived from https://www.neliti.com/publications/43318/perlindungan-terhadap anak-yang-berhadapan-dengan-hukum-melalui-pendekatan-resto\#cite, hlm. 151 
Bentuk keadilan restoratif yang digunakan dalam Undang-Undang Sistem Peradilan Pidana Anak adalah diversi. Menurut Pasal 1 Angka 7 Undang-Undang Nomor 11 Tahun 2012 Tentang Sistem Peradilan Pidana Anak, yang dimaksud diversi adalah "pengalihan penyelesaian perkara Anak dari prosesperadilan pidana ke proses di luar peradilan pidana”. Dan pada Pasal 7 Undang-Undang Nomor 11 Tahun 2012 Tentang Sistem Peradilan Pidana Anak menyebutkan:

(1) Pada tingkat penyidikan, penuntutan, dan pemeriksaan perkara Anak di pengadilan negeri wajib diupayakan Diversi.

(2) Diversi sebagaimana dimaksud pada ayat (1) dilaksanakan dalam hal tindak pidana yang dilakukan:

a. diancam dengan pidana penjara di bawah 7 (tujuh) tahun; dan

b. bukan merupakan pengulangan tindak pidana.

Secara dogmatik diversi pada anak penyalah guna narkotika dapat diupayakan sesuai dengan Pasal 9 ayat 2 huruf C Undang-Undang Nomor 11 Tahun 2012 Tentang Sistem Peradilan Pidana Anak, yang menyatakan "Kesepakatan Diversi harus mendapatkan persetujuan korban dan/atau keluarga Anak Korban serta kesediaan Anak dan keluarganya, kecuali untuk tindak pidana tanpa korban". Karena jika melihat pasal 127 Undang-Undang Nomor 35 Tahun 2009 Tentang Narkotika, yang ancaman pidananya paling lama 4 (empat) tahun. Maka salah satu syarat diversi dapat dilaksanakan telah terpenuhi, yaitu dapat dilakukan diversi apabila ancaman pidana yang dilakukan anak di bawah 7 (tujuh) tahun seperti yang tercantum dalam Pasal 7 Undang-Undang Nomor 11 Tahun 2012 Tentang Sistem Peradilan Pidana Anak.

Untuk menentukan penyalah guna narkotika adalah Mutual Victimization pada anak. Perlu dilakukannya penelitian kemasyaraktan yang dilakukan oleh Balalai Pemasyarakatan yang selanjutnya disebut Bapas.52 Dari hasil penelitain oleh Bapas tersebut dapat dilihat faktor penyebab anak melakukan tindak pidana, yang dapat pula menentukan bentuk pertanggung jawaban kotban sebagai Selfvictimizing victims dari hasil penelitian tersebut. Anak penyalah guna narkotika menurut ilmu viktimologi dapat dikategorikan sebagai The Young, yaitu orang berusia muda yang dapat mudah menjadi korban.

“Menurut Undang-Undang Nomor 11 Tahun 2012 Tentang Sistem Peradilan Pidana Anak, Pasal 69 ayat (2), anak yang belum berusia 14 (empat belas) tahun hanya dapat dikenakan tindakan. Sedangkan Pasal 70 menyatakan bahwa ringannya perbuatan, keadaan pribadi anak, atau kemudian dapat dijadikan dasar pertimbangan hakim untuk tidak menjatuhkan pidana atau mengenakan tindakan dengan mempertimbangkan segi keadilan dan kemanusiaan."53

52 Lihat Pasal 1 angka 24 Undang-Undang Nomor 11 Tahun 2012 Tentang Sistem Peradilan

Pidana

53 Abintoro Prakoso, Pembaruan Sistem Peradilan Pidana Anak, Laksbang Grafika, Yogyakarta, 2013, hlm. 89 
Yang artinya hasil penelitian Bapas merupakan sangat berpengaruh dalam menentukan proses diversi anak, serta unutk kepentingan selama proses peradilan pidana anak. Yang hasil penelitian tersebut akan menjadi dasar pertimbangan hakim dalam menjatuhkan pidana atau mengenakan tindakan.

"Menurut Hegel, di dalam menjatuhkan suatu pidana, pribadi dari pelakunya tetap dihormati, dalam arti bahwa berat atau ringannya pidana yang dapat dijatuhkan bagi pelaku tersebut haruslah ditentukan oleh jenis perbuatan yang telah dilakukan oleh pelaku itu sendiri." 54

Menurut sistem Undang-Undang Perlindungan Anak, penjatuhan sanksi yang tepat untuk kepentingan anak dilaksanakan melalui upaya rehabilitasi. ${ }^{55}$ Penyalah guna narkotika yang merupakan pelaku sekaligus korban yang menurut UndangUndang Nomor 35 Tahun 2014 Tentang perubahan Undang-Undang Republik Indonesia Nomor 23 Tahun 2002 Tentang Perlindungan Anak, maka anak penyalah guna narkotika diberikan perlindugan khusus. Perlindungan tersebut berupa penangan yang cepat, termasuk pengobatan dan/ atau rehabilitasi secara fisik, psikis, dan sosial, serta pencegahan penyakit gangguan kesehatan lainnya. ${ }^{56} \mathrm{Hal}$ tersebut tercantum pada Pasal 67 Undang-Undang Nomor 35 Tahun 2014 Tentang perubahan Undang-Undang Republik Indonesia Nomor 23 Tahun 2002 Tentang Perlindungan Anak, menyebutkan :

"Perlindungan khusus bagi Anak yang menjadi korban penyalahgunaan narkotika, alkhol, psikotropika, dan zat adiktif lainnya sebagaimana dimaksud dalam Pasal 59 ayat (2) huruf e dan Anak yang terlibat dalam produksi dan sitribusinya dilakukan melalui upaya pencegahan, perawatan, dan rehabilitasi."

Maka anak penyalah guna narkotika adalah korban yang wajib diberikan perlindungan dan dijauhkan dari upaya pemidananaan. Namun, jika melihat perkara anak penyalahguna narkotika yang ditemui di dalam masyarakat, khususnya dalam wilayah hukum Pengadilan Negeri Jambi, dapat dilihat pada tabel 1.

Memperhatikan pada tabel 1 yang datanya diambil dari Sistem Informasi Perkara Pengadilan Negeri Jambi, menunjukan bahwa terhadap anak penyalah guna narkotika putusan penjara lebih dominan diberikan sebagai reaksi terhadap anak penyalah guna narkotika.Artinya, hal tersebut bertentangan dengan semangat untuk mengedepankan keadilan resoratif dan pemberian hak rehabilitasi terhadap penyalah guna narkotika terutama pelakunya adalah anak.Serta melindungi kepentingan anak sesuai dengan Undang-Undang Sistem Peradilan Pidana Anak.Karena penyalah guna narkotika tetap dianggap sebagai pelaku tindak pidana bukanlah korban.

54 P.A.F Lamintang dan Theo Lamintang, Hukum Panitensier Indonesia, Sinar Grafika, Jakarta, 2010, hlm.13

55 Harrys Pratama Teguh, Ibid, hlm. 42

56 Lihat Pasal 59A Undang-Undang Nomor 35 Tahun 2014 Tentang perubahan Undang Undang Republik Indonesia Nomor 23 Tahun 2002 Tentang Perlindungan Anak 
Sementara disadari bahwa pidana penjara yang berdasarkan penelitian ${ }^{57}$ tidak sedikit menimbulkan dampak negatif bagi narapidana, apalagi anak-anak yang sangat berpengaruh terhadap perkembangan fisik, mental, dan sosial anak.

"Dari aspek praktis penyalah guna narkotika bisa dikatakan 99\% penyalah guna narkotika adalah pecandu sehingga dapat dikatakan sesungguhnya Pasal 127 yang menetapkan sanksi pidana atau kriminalisasi terhadap pelaku penyalah guna narkotika sejatinya tidak harus diterapkan karena undangundang narkotika telah memerintahkan bahwa terhadap pecandu harus direhabilitasi baik secara medis maupun rehabilitasi sosial..."58

Upaya penjauhan anak penyalah guna narkotika dari putusan pemidanaan penjara yang merampas kemerdekaan anak sebagai bentuk pembalasan tindak pidana, dapat dihindari dengan cara diversi sebagai bentuk keadilan restoratif yang diatur dalam Undang-Undang Sistem Peradilan Pidana. Ataupun upaya rehabilitasi yang diatur dalam Undang-Undang Perlindungan Anak.

Hal tersebut sering tidak berjalan karena dalam Undang-Undang Narkotika penyalah guna narkotika tetap dianggap pelaku tindak pidana. Tidak secara murni dianggap korban tindak pidana, hal tersebut menyebabkan adanya standar ganda dalam pemberian keputusan yang seharusnya melindungi korban penyalah guna narkotika khususnya pada anak.

Dengan memperhatikan Undang-Undang Nomor 11 Tahun 2012 Tentang Sistem Peradilan Pidana Anak, serta Undang-Undang Nomor 35 Tahun 2014 Tentang perubahan Undang-Undang Republik Indonesia Nomor 23 Tahun 2002 Tentang Perlindungan Anak, dapat memberikan landasan hukum kuat untuk membedakan perlakuan terhadap anak penyalah guna narkotika bukan merupakan semata-mata sebagai pelaku namun juga sebagai korban. Karena untuk terjadinya tindak pidana yang dilakukan oleh anak, banyak sekali faktor yang menyebabkan hal tersebut terjadi. Sehingga perlu kejelasan mengenai perlindungan anak sebagai penyalah guna narkotika dari upaya pidana penjara. Masalah ini sudah selayaknya mendapatkan perhatian khusus dari aparat penegak hukum dalam memperoses dan memutuskan keputusan yang akan diambil untuk mengatur dan mengembalikan masa depan anak sebagai warga negara yang bertanggung jawab dalam masyarakat

57 Hafrida, Yulia Monita, dan Elizabeth Siregar. "Pembinaan Narapidana Anak Di Lembaga Pemasyarakatan Anak Sei. Bulu Muara Bulian”, Jurnal Publikasi Pendidikan. Volume 5 Nomor 3, September 2015. Retrieved https://ojs.unm.ac.id/pubpend/article/view/1613.

58 Analisis Putusan Hakim Pengadilan Negeri Jambi terhadap Pengguna/ Pemakai Narkotika dalam Perspektif Penanggulangan Tindak Pidana Narkotika di Kota Jambi." Jurnal Penelitian Universitas Jambi: Seri Humaniora, vol. 16, Nomor 1, 2014. Retrieved from https://www.neliti.com/publications/43461/analisis-putusan-hakim-pengadilan negeri jambi- terhadap-pengguna-pemakai-narkoti\#cite, hlm.66. 
Tabel 1

Bentuk Putusan Hakim dalam Perkara Anak Penyalah Guna Narkotika di Wilayah Hukum Pengadilan Negeri Jambi pada tahun 2016-2019 (Agustus)

\begin{tabular}{|c|c|c|c|}
\hline No & Nomor Putusan & $\begin{array}{c}\text { Pasal Yang Dikenakan } \\
\text { Pada Anak }\end{array}$ & Jenis Putusan \\
\hline 1 & $\begin{array}{c}\text { 2/Pid.Sus- } \\
\text { Anak/2016/PN. Jmb }\end{array}$ & $\begin{array}{l}127 \text { ayat } 1 \text { UU No. } 35 \text { Th. } \\
2009\end{array}$ & Penjara 8 bulan \\
\hline 2 & $\begin{array}{c}\text { 14/Pid.Sus- } \\
\text { Anak/2016/PN. Jmb }\end{array}$ & $\begin{array}{l}127 \text { ayat } 1 \text { UU No. } 35 \text { Th. } \\
2009\end{array}$ & Penjara 1 tahun \\
\hline 3 & $\begin{array}{c}\text { 19/Pid.Sus- } \\
\text { Anak/2016/PN. Jmb }\end{array}$ & $\begin{array}{l}127 \text { ayat } 1 \text { UU No. } 35 \text { Th. } \\
2009\end{array}$ & Penjara 1,2 tahun \\
\hline 4 & $\begin{array}{c}\text { 20/Pid.Sus- } \\
\text { Anak/2016/PN. Jmb }\end{array}$ & $\begin{array}{l}127 \text { ayat } 1 \text { UU No. } 35 \text { Th. } \\
2009\end{array}$ & Penjara 1,4 tahun \\
\hline 5 & $\begin{array}{c}\text { 23/Pid.Sus- } \\
\text { Anak/2016/PN. Jmb }\end{array}$ & $\begin{array}{l}127 \text { ayat } 1 \text { UU No. } 35 \text { Th. } \\
2009\end{array}$ & Penjara 1,4 tahun \\
\hline 6 & $\begin{array}{c}\text { 24/Pid.Sus- } \\
\text { Anak/2016/PN. Jmb }\end{array}$ & $\begin{array}{l}127 \text { ayat } 1 \text { UU No. } 35 \text { Th. } \\
2009\end{array}$ & Penjara 1,4 tahun \\
\hline 7 & $\begin{array}{c}\text { 26/Pid.Sus- } \\
\text { Anak/2016/PN. Jmb }\end{array}$ & $\begin{array}{l}127 \text { ayat } 1 \text { UU No. } 35 \text { Th. } \\
2009\end{array}$ & Penjara 1,4 tahun \\
\hline 8 & $\begin{array}{c}\text { 41/Pid.Sus- } \\
\text { Anak/2016/PN. Jmb }\end{array}$ & $\begin{array}{l}127 \text { ayat } 1 \text { UU No. } 35 \text { Th. } \\
2009\end{array}$ & Penjara 1 tahun \\
\hline 9 & $\begin{array}{c}\text { 12/Pid.Sus- } \\
\text { Anak/2017/PN. Jmb }\end{array}$ & $\begin{array}{l}127 \text { ayat } 1 \text { UU No. } 35 \text { Th. } \\
2009\end{array}$ & Penjara 10 bulan \\
\hline 10 & $\begin{array}{c}\text { 13/Pid.Sus- } \\
\text { Anak/2017/PN. Jmb }\end{array}$ & $\begin{array}{l}127 \text { ayat } 1 \text { UU No. } 35 \text { Th. } \\
2009\end{array}$ & Penjara 10 bulan \\
\hline 11 & $\begin{array}{c}\text { 19/Pid.Sus- } \\
\text { Anak/2018/PN. Jmb }\end{array}$ & $\begin{array}{l}127 \text { ayat } 1 \text { UU No. } 35 \text { Th. } \\
2009\end{array}$ & Penjara 1 tahun \\
\hline 12 & $\begin{array}{c}\text { 23/Pid.Sus- } \\
\text { Anak/2018/PN. Jambi }\end{array}$ & $\begin{array}{l}127 \text { ayat } 1 \text { UU No. } 35 \text { Th. } \\
2009\end{array}$ & Penjara 1 tahun \\
\hline 13 & $\begin{array}{c}\text { 8/Pid.Sus- } \\
\text { Anak/2019/PN. Jmb }\end{array}$ & $\begin{array}{l}127 \text { ayat } 1 \text { UU No. } 35 \text { Th. } \\
2009\end{array}$ & Rehabilitasi \\
\hline
\end{tabular}

Sumber Data: Sistem Informasi Penelusuran Perkara Pengadilan Negeri Jambi

\section{B. METODE PENELITIAN}

Penelitian ini menggunakan metode pendekatan yuridis normatif, yaitu penelitian yang dilakukan atau dituju hanya pada peraturan-peraturan tertulis atau bahan-bahan hukum primer meliputi peraturan perundangan, bahan hukum skunder terdiri dari buku, jurnal, dan literatur lainnya. Pendekatan yang digunakan adalah pendekatan undang-undang, pendekatan konseptual, dan pendekatan kasus. 


\section{PEMBAHASAN}

1. Anak Penyalah Guna Narkotika Di Wilayah Hukum Pengadilan Negeri Jambi dam Perspektif Victimologi

Untuk mengetahui adanya faktor viktimisasi anak sebagai penyalah guna narkotika perlu dilihat pula sebab-sebab anak melakukan tindak pidana yang menjadikan anak tersebut penyalah guna.Maka unutk menemukan ada tidaknya faktor viktimisasi anak penyalah guna narkotika, penulis melihat hal tersebut dari putusan pengadilan dan hasil laporan penelitian kemasyarakatan yang dilakukan oleh Bapas.

Tabel 2

Jenis Putusan Hakim dalam Perkara Anak Penyalah Guna Narkotika di Wilayah Hukum Pengadilan Negeri Jambi pada tahun 2016-2019 (Agustus)

\begin{tabular}{|c|c|c|c|}
\hline No & Nomor Putusan & $\begin{array}{c}\text { Pasal Yang Dikenakan } \\
\text { Pada Anak }\end{array}$ & Jenis Putusan \\
\hline 1 & $\begin{array}{c}\text { 2/Pid.Sus- } \\
\text { Anak/2016/PN. Jmb }\end{array}$ & $\begin{array}{c}127 \text { ayat } 1 \text { UU No. } 35 \text { Th. } \\
2009\end{array}$ & Penjara 8 bulan \\
\hline 2 & $\begin{array}{c}\text { 14/Pid.Sus- } \\
\text { Anak/2016/PN. Jmb }\end{array}$ & $\begin{array}{c}127 \text { ayat } 1 \text { UU No. } 35 \text { Th. } \\
2009\end{array}$ & Penjara 1 tahun \\
\hline 3 & $\begin{array}{c}\text { 19/Pid.Sus- } \\
\text { Anak/2016/PN. Jmb }\end{array}$ & $\begin{array}{c}127 \text { ayat } 1 \text { UU No. } 35 \text { Th. } \\
2009\end{array}$ & Penjara 1,2 tahun \\
\hline 4 & $\begin{array}{c}\text { 20/Pid.Sus- } \\
\text { Anak/2016/PN. Jmb }\end{array}$ & $\begin{array}{l}127 \text { ayat } 1 \text { UU No. } 35 \text { Th. } \\
2009\end{array}$ & Penjara 1,4 tahun \\
\hline 5 & $\begin{array}{c}\text { 23/Pid.Sus- } \\
\text { Anak/2016/PN. Jmb }\end{array}$ & $\begin{array}{l}127 \text { ayat } 1 \text { UU No. } 35 \text { Th. } \\
2009\end{array}$ & Penjara 1,4 tahun \\
\hline 6 & $\begin{array}{c}\text { 24/Pid.Sus- } \\
\text { Anak/2016/PN. Jmb }\end{array}$ & $\begin{array}{l}127 \text { ayat } 1 \text { UU No. } 35 \text { Th. } \\
2009\end{array}$ & Penjara 1,4 tahun \\
\hline 7 & $\begin{array}{c}\text { 26/Pid.Sus- } \\
\text { Anak/2016/PN. Jmb }\end{array}$ & $\begin{array}{c}127 \text { ayat } 1 \text { UU No. } 35 \text { Th. } \\
2009\end{array}$ & Penjara 1,4 tahun \\
\hline 8 & $\begin{array}{c}\text { 41/Pid.Sus- } \\
\text { Anak/2016/PN. Jmb }\end{array}$ & $\begin{array}{l}127 \text { ayat } 1 \text { UU No. } 35 \text { Th. } \\
2009\end{array}$ & Penjara 1 tahun \\
\hline 9 & $\begin{array}{c}\text { 12/Pid.Sus- } \\
\text { Anak/2017/PN. Jmb }\end{array}$ & $\begin{array}{c}127 \text { ayat } 1 \text { UU No. } 35 \text { Th. } \\
2009\end{array}$ & Penjara 10 bulan \\
\hline 10 & $\begin{array}{c}\text { 13/Pid.Sus- } \\
\text { Anak/2017/PN. Jmb }\end{array}$ & $\begin{array}{l}127 \text { ayat } 1 \text { UU No. } 35 \text { Th. } \\
2009\end{array}$ & Penjara 10 bulan \\
\hline 11 & $\begin{array}{c}\text { 19/Pid.Sus- } \\
\text { Anak/2018/PN. Jmb }\end{array}$ & $\begin{array}{l}127 \text { ayat } 1 \text { UU No. } 35 \text { Th. } \\
2009\end{array}$ & Penjara 1 tahun \\
\hline 12 & $\begin{array}{c}\text { 23/Pid.Sus- } \\
\text { Anak/2018/PN. Jambi }\end{array}$ & $\begin{array}{c}127 \text { ayat } 1 \text { UU No. } 35 \text { Th. } \\
2009\end{array}$ & Penjara 1 tahun \\
\hline 13 & $\begin{array}{c}\text { 8/Pid.Sus- } \\
\text { Anak/2019/PN. Jmb }\end{array}$ & $\begin{array}{l}127 \text { ayat } 1 \text { UU No. } 35 \text { Th. } \\
2009\end{array}$ & Rehabilitasi \\
\hline
\end{tabular}

Sumber Data: Sistem Informasi Penelusuran Perkara Pengadilan Negeri Jambi 
Terdapat total 13 (tiga belas) putusan mengenai anak penyalah guna narkotika yang diputus dengan Pasal 127 Undang-Undang Nomor 35 Tahun 2009 Tentang Narkotika di wilayah hukum Pengadilan Negeri Jambi dari rentang waktu tahun 2016 sampai dengan tahun 2019 (Agustus), seperti pada tabel 2.

Berdasarkan data di atas terdapat 2 (dua) jenis putusan yang Hakim jatuhkan kepada anak penyalah guna narkotika, yaitu pidana penjara dan tindakan rehabilitasi.Putusan yang memberikan pidana penjara lebih dominan dari pada putusan berupa tindakan rehabilitasi.Namun dari 13 (tiga belas) putusan, penulis hanya menyajikan 3 (tiga) putusan pengadilan untuk mengetahui viktimisasi anak penyalah guna narkotika berdasarkan sebab-sebab anak menjadi penyalah guna narkotika di wilayah hukum Pengadilan Negeri Jambi. 3 (tiga) putusan ini penulis peroleh secara acak yang mana ketiga putusan ini dianggap mewakili 13 (tiga belas) putusan lainnya.Yaitu, putusan nomor 13/Pid.Sus-Anak/2017/PN.Jmb, putusan nomor 19/Pid.Sus-Anak/2018/PN.Jmb, dan putusan nomor 23/Pid.Sus-Anak/2018/PN. Jmb, yaseperti pada tabel 3.

Berdasarkan uraian tabel 3 yang datanya diperoleh dari laporan yang dibuat oleh Bapas.Dapat dianalisis faktor yang menyebabkan anak dapat dikatakan sebagai korban penyalahgunaan narkotika berdasarkan sebab-sebab anak terlibat dalam penyalahgunaan narkotika. Menurut Romli Atmasari, apabila dilihat penyebab anak melakukan tindak pidana hal tersebut timbul akibat adanya motivasi, yang dibedakan secara intrinsik maupun ekstrinsik ${ }^{59}$.

Pokok-pokok penyebab anak menjadi penyalah guna narkotika ini apabila dilihat dari motivasi intrinsik, faktor intelegensia, faktor usia, dan faktor kedudukan anak dalam keluarga sangat terlihat mempengaruhi ketiga perkara anak menjadi penyalah guna narkotika. Seperti dalam perkara nomor 13/Pid.SusAnak/2017/PN. Jmb, faktor intelegensia dapat dilihat dimana "Anak" menggunakan narkotika golongan shabu karena beranggapan bahwa shabushabu dapat menambah tenaga dan menghilangkan kantuk saat bekerja. Hal tersebut mengartikan bahwa pengetahuan "Anak" mengenai dampak penggunaan narkotika sangat minim, sehingga "Anak" menganggap shabu adalah hal lumrah untuk dikonsumsi untuk menambah tenaga dan menghilangkan kantuk saat bekerja. "Anak" pun terpaksa bekerja karena kedudukanya dalam keluarga adalah salah satu orang yang diandalkan dalam membantu perekonomian keluarga. Dalam ketiga perkara tersebut pula terdapat kesamaan dimana anak kedudukan dikeluarganya sebagai salah satu yang mencari nafkah untuk membantu perekonomian keluarga. Padahal dari segi usia anak-anak tersebut berusia antara16 (enam belas) sampai 17 (tujuh belas) tahun.

${ }^{59}$ Loc.Cit 
Tabel 4

Faktor Viktimisasi Anak Penyalah Guna Narkotika di Wilayah Hukum Pengadilan Negeri Jambi pada tahun 2016-2019 (Agustus)

\begin{tabular}{|c|c|c|c|}
\hline No & $\begin{array}{l}\text { Nomor } \\
\text { Putusan }\end{array}$ & $\begin{array}{c}\text { Sebab-Sebab Anak } \\
\text { Menggunakan Narkotika }\end{array}$ & $\begin{array}{c}\text { Kesimpulan Hasil } \\
\text { Rekomendasi Bapas }\end{array}$ \\
\hline 1 & $\begin{array}{c}\text { 13/Pid.Sus- } \\
\text { Anak/2017/P } \\
\text { N. Jmb }\end{array}$ & $\begin{array}{l}\text { Faktor utama penyebab } \\
\text { "Anak" terlibat dalam tindak } \\
\text { pidana ini adalah faktor } \\
\text { pergaulan yang mana "Anak" } \\
\text { berteman yangtanpa } \\
\text { sepengetahuannya merupakan } \\
\text { orang yang terlibat dalam } \\
\text { sindikat peredaran Narkotika. } \\
\text { Faktor lain yang turut } \\
\text { berperan adalah: } \\
\text { a. Faktor usia dan mental yang } \\
\text { mana usia "Anak" yang } \\
\text { masih muda, belum bisa } \\
\text { memikirkan akibat yang } \\
\text { timbul atas perbuatannya } \\
\text { b. Adanya anggapan dari } \\
\text { "Anak" bahwa shabu-shabu } \\
\text { dapat menambah tenagadan } \\
\text { menghilangkan kantuk saat } \\
\text { bekerja } \\
\text { c. Faktor dari keluarga berupa } \\
\text { kurangnya pengawasan dari } \\
\text { orang tua }\end{array}$ & \begin{tabular}{l}
\multicolumn{1}{c}{ Bapas, dengan } \\
mengedepankan \\
kepentingan terbaik bagi \\
anak dengan mengacu \\
kepada Undang-Undang \\
Nomor 11 Tahun 2012 \\
tentang Sistem Peradilan \\
Pidana Anak. Bapas \\
merekomendasikan \\
"Anak" dijatuhi Pidana \\
penjara dengan seringan- \\
ringannya
\end{tabular} \\
\hline 2 & $\begin{array}{c}\text { 19/Pid.Sus- } \\
\text { Anak/2018/P } \\
\text { N. Jmb }\end{array}$ & $\begin{array}{l}\text { Tindak pidana yang dilakukan } \\
\text { oleh "Anak" disebabkan oleh } \\
\text { beberapa hal yang saling } \\
\text { berkaitan yaitu: } \\
\text { a. Kondisi kejiwaan "Anak" } \\
\text { yang masih labil yang terkait } \\
\text { erat dengan usia "Anak" } \\
\text { yang masih tergolong masih } \\
\text { remaja. } \\
\text { b. Lemahnya pelaksanaan } \\
\text { fungsi kontrol sosial baik } \\
\text { yang dilakukan oleh wali/ } \\
\text { orang tua "Anak" terhadap } \\
\text { "Anak" maupun kontrol } \\
\text { sosial oleh masyarakat. }\end{array}$ & $\begin{array}{l}\text { Bapas pertama } \\
\text { merekomendasikan ANAK } \\
\text { pidana tindakan berupa } \\
\text { rehabilitasi medis dan } \\
\text { sosial di Rumah Sakit Jiwa } \\
\text { Provinsi Jambi, } \\
\text { berdasarka Pasal } 82 \text { ayat } \\
\text { (1) huruf c angka } 13 \\
\text { Undang-Undang Nomor } \\
11 \text { Tahun } 2012 \text { Tentang } \\
\text { Sistem Peradilan Pidana } \\
\text { Anak dan Pasal } 1 \text { angka } \\
13 \text { Undang-Undang } \\
\text { Nomor } 35 \text { Tahun } 2009 \\
\text { Tentang Narkotika yang } \\
\text { menyatakan bahwa }\end{array}$ \\
\hline
\end{tabular}




\begin{tabular}{cll} 
& & $\begin{array}{l}\text { Pencandu Narkotika } \\
\text { adalah orang yang } \\
\text { menggunakan atau } \\
\text { menyalahgunakan } \\
\text { narkotika dalam keadaan } \\
\end{array}$ \\
& & $\begin{array}{l}\text { ketergantungan pada } \\
\text { narkotika, baik secara } \\
\text { fisik maupun psikis. }\end{array}$ \\
\hline 23/Pid.Sus- & Faktor utama penyebab & Dengan mengedepankan \\
Anak/2018/P & "Anak" terlibat dalam tindak & kepentingan terbaik bagi \\
N. Jmb & pidana ini adalah karena & anak dengan mengacu \\
& pergaulan yang salah serta & kepada Undang-Undang \\
& kebiasaan "Anak" bermain di & Nomor 11 Tahun 2012 \\
& warnet hingga larut malam. & tentang Sistem Peradilan \\
& & Pidana Anak. Bapas \\
& & merekomendasikan \\
& & "Anak" dijatuhi Pidana \\
& & penjara dengan seringan- \\
& & ringannya
\end{tabular}

Sumber Data: Hasil laporan penelitian kemasyarakatan yang dilakukan oleh Bapas

Dari motivasi ekstrinsik, faktor keluarga, faktor pendidikan dan sekolah, serta faktor pergaulan anak dalam ketiga perkara anak ini sangat mempengaruhi anak menjadi penyalah guna narkotika.Karena dalam ketiga perkara ini terdapat kesamaan dalam faktor motivasi ekstrinsik.Yaitu faktor keluarga yang kurang dalam, pengawasan terhadap anak, dan menyebabkan anak dapat menjadi penyalah guna narkotika. Faktor pendidikan dan sekolah anak, yang mana dalam ketiga perkara ini ketiganya anak sama-sama hanya bersekolah sampai jenjang SD dan tidak melanjutkan ke jenjang berikutnya karena harus membantu perekonomian keluarga.Dalam faktor pergaulan anak, ketiganya karena samasama kurangnya pengawasan orang tua, anak bergaul dengan orang lebih dewasa yang cenderung melakukan tindakan kriminal sehingga anak pun mengikutinya.Pada perkara 23/Pid.Sus-Anak/2018/PN.Jmb "Anak" selain menjadi penyalah guna narkotika, juga terlibat dalam peredaran gelap narkotika akibat "Anak" salah bergaul dan "Anak" dibujuk dengan imbalan agar menuruti perkataan temannya.

Jika dilihat peran korban dalam menimbulkan kejahatan seperti yang dikemukakan Arief Gosita60, anak menjadi penyalah guna narkotika memang dikehendaki oleh dirinya sendiri. Yang berdasarkan tingkat keterlibatan korban kejahatan anak termasuk Mutual Victimization. Sedangkan dalam pertanggung

${ }^{60}$ Rena Yulia, Ibid hlm.49 
jawaban korban seperti yang dikemukakan Stephen Schefer61, anak sebagai korban menanggung sepenuhnya pertanggungjawaban sebagai pelaku kejahatan yang dilakukannya sendiri dengan kata lain anak termasuk Selfvictimizing victims. Apabila berdasarkan faktor psikologis, sosial, dan biologik seperti yagn dikemukakan von Hetig, anak dapat dikategorikan sebagai The Young, yaitu orang yang masih muda atau anak-anak yang sangat mudah menjadi target kejahatan bukan hanya fisik namun juga karena belum matang kepribadian dan ketahanan moralitas. Karena anak mengalami penderitaan fisik dan mental akibat dari penyalahgunaan narkotika yang dilakukannya sendiri, anak dapat dikatakan sebagai korban.Berdasarkan faktor psikologis, sosial, dan biologis mengenai anak penyalah guna narkotika adalah The Young.Maka menurutSthepen Schefer apabila melihat menganai pertanggungjawaban korban anak penyalah guna narkotika termasuk pula Biologically weak victim. Yang pertanggung jawabannya terletak pada masyarakat atau pemerintah setempat karena tidak dapat memberi perlindungan kepada korban yang tidak berdaya.

Berdasarkan penjelasan Pasal 54 Undang-Undang Tentang Narkotika yang menyebutkan korban penyalah guna adalah seorang yang tidak sengaja menggunakan narkotika karena dibujuk, diperdaya, ditipu, dipaksa, dan/atau diancam untuk menggunakan narkotika.Dalam ketiga perkara in terdapat upaya agar anak dibujuk, dirayu, atau diperdaya oleh lingkungan teman-temannya untuk menggunakan narkotika.Dalam perkaran nomor 13/Pid.SusAnak/2017/PN. Jmb berdasarkan laporan penelitian oleh Bapas yang menyatakan sebab "Anak" menggunakan narkotika karena ia beranggapan bahwa shabu-shabu dapat menambah tenaga dan menghilangkan kantuk saat bekerja. Maka ada kemungkinan besar "Anak" menggunakan narkotika karena dibujuk ataupun dirayu oleh lingkungan pertemanannya.Sama halnya pada perkaran nomor 19/Pid.Sus-Anak/2018/PN.Jmb berdasarkan kesaksian "Anak" dan Udin dalam putusan pengadilan yang menyatakan bahwa benar bahwa Udin mengajak "Anak" untuk membeli dan menggunakan narkotika jenis shabu, dan "Anak" hanya mengikuti ajakan dari Udin.Sedangkan pada perkara nomor 23/Pid.Sus-Anak/2018/PN. Jmb berdasarkan laporan penelitian oleh Bapas dan kesesaksian "Anak" sendiri dalam Putusan Pengadilan yang menyatakan anak melakukan tindak pidana narkotika karena ada upaya bujuk rayu dari Dian Als. Ayambu yang menjanjikan sejumlah uang padanya sebesar Rp.50.000,- hanya untuk menyimpan 5 (lima) paket narkotika di dalam kamar mandi Herman.

\section{Kebijakan Hukum Pidana Mengenai Anak Penyalah Guna Narkotika Sebagai Korban bukan sebagai Pelaku Tindak Pidana}

Kebijakan hukum atau penal policy merupakan sarana untuk menanggulangi kejahatan dengan menggunakan pidana. Berdasarkan pemikiran di atas, selanjutnya Sudarto menyatakan bahwa kebijakan atau politik hukum pidana (penal policy) adalah usaha mewujudkan peraturan perundang-undangan pidana

${ }^{61}$ Mahrus Ali, Op. Cit, hlm. 57 
yang sesuai dengan keadaan dan situasi pada suatu waktu dan untuk masa-masa yang akan datang. ${ }^{62}$

Pengertian yang serupa dikemukakan oleh Marc Ancel, bahwa penal policy adalah suatu ilmu sekaligus seni yang pada akhirnya mempunyai tujuan praktis untuk memungkinkan peraturan hukum positif dirumuskan secara lebih baik dan untuk memberikan pedoman tidak hanya kepada pembuat undang-undang dan juga kepada pengadilan yang menerapkan undangundang dan juga kepada penyelenggaraan atau pelaksana keputusan. ${ }^{63}$

Dari beberapa pendapat di atas, maka kebijakan hukum pidana mengenai viktimisasi anak penyalah guna narkotika sebagai suatu sarana menanggulangi penyalahgunaan narkotika di kalangan anak-anak khususnya sebagai penyalah guna narkotika. Atau, dapat berarti pula sebagai suatu usaha untuk mewujudkan suatu peraturan perundang-undangan hukum pidana yang baik sesuai dengan situasi dan kondisi pada suatu waktu.

Karena berdasarkan putusan perkara anak yang menjadi penyalah guna narkotika di wilayah hukum Pengadilan Negeri Jambi.Pola pikir dalam menjatuhkan pidana yang menyamakan anak penyalah guna narkotika sebagai pelaku perdagangan gelap narkotika dan hal tersebut dapat berpotensi melanggar hak-hak anak yang harus dilindungi.Seperti yang telah dikemukakan sebelumnya, bahwa anak menjadi penyalah guna narkotika lebih dominan akibat dorongan dari luar diri anak.Yang hal tersebut menyebabkan anak sangat rentan menjadi korban penyalah guna narkotika.Kebijakan terhadap anak korban penyalah guna narkotika seharusnya dilakukan dengan pendekatan restoratif dengan mengedepankan penjauhan anak dari upaya pemidanaan.Seperti menjatuhkan pidana tindakan berupa rehabilitasi baik kesehatan dan sosial, atau pun dapat pula dikenakan tindakan pada anak seperti pelatihan kerja.

Pendekatan restoratif yang mengedepankan penyelesaian perkara anak di luar pengadilan dalam Undang-Undangg Sistem Peradilan Anak dikenal dengan diversi. Sebenarnya hal dapat dilakukan terhadap anak penyalah guna narkotika. Yang mana ancaman pidana pada Pasal 127 Undang-Undang Nomor 35 Tahun 2009 Tentang Narkotika yaitu 4 (empat) tahun, hal tersebut telah memenuhi salah satu syarat untuk dilakukannya diversi yang mana ancaman pidana yang dikenakan pada anak di bawah 7 (tujuh) tahun. Namun hal tersebut sering terkendala dikarenakan anak tetap dianggap pelaku tindak pidan bukannya korban penyalah guna narkotika.Sehingga anak juga diancam dengan pasal-pasal yang pidana penjaranya lebih dari pada 7 (tujuh) tahun.

Dengan melihat adanya faktor viktimisasi anak penyalah guna narkotika yang seharusnya anak penyalah guna narkotika seharusnya dianggap korban bukan pelaku, bahkan seharusnya apabila dianggap sebagai pelaku pun anak penyalah guna narkotika berdasarkan Undang-Undang Sistem Peradilan Pidana Anak tetap dapat diupayakan diversi.Namun, berdasarkan laporan penelitian yang dilakukan oleh Bapas terhadap 3 (tiga) perkara anak penyalah guna narkotika yang sebelumnya penulis paparkan, upaya diversi tidak diupayakan

62 Barda Nawawi Arief, Op. Cit. hlm.26

63 Ibid, hlm. 27 
oleh Bapas pada 3 (tiga) perkara tersebut.Karena pada laporannya anak penyalah guna narkotika tetap dianggap sebagai pelaku.Seperti pada perkara nomor 19/Pid.Sus-Anak/2018/PN.Jmb alasan tidak dilakukan diversi karena penyalah guna narkotika adalah tindak pidana tanpa korban, maka tidak dapat diupayakan diversi. Alasan ini dianggap tidak tepat, karena seharusnya secara dogmatik sesuai Pasal 9 ayat 2 huruf C Undang-Undang Sistem Peradilan Pidana Anak, tindak pidana tanpa korban dapat dilakukan upaya diversi

Penyadaran bahwa anak adalah korban penyalah guna narkotika dan dijauhkan dari upaya pemidanaan dengan pemberian rehabilitasi perlu dilakukan. Karena selain upaya tersebut lebih humanis dan upaya pemulihan yang jauh dari keterpaksaan, ketimbang pemberian pidana penjara yang malah akan berdampak merampas hak-hak yang dimiliki oleh anak. Serta menjauhkan anak dari dampak negatif dari proses pemidanaan.

Menurut Barda Nawawi Arief seperti yang dikutip Koesno Adi, konsep kenakalan anak tidak ada bedanya dengan kejahatan dengan pelanggaran, namun pada hakekatnya yang mendasari peradilan anak adalah adanya perlindungan hak-hak anak untuk mewujudkan kesejahteraan anak. Dalam menangani masalah hukum dan pengadilan anak ini pun perlu pendekatan pendekatan khusus, antara lain yang sering terungkap dalam berbagai pernyataan: ${ }^{64}$

1. Anak melakukan tindak pidana/kejahatan (juvenile offender) janganlah dipandang sebagai seorang penjahat (criminal), tetapi harus dilihat sebagai orang yang memerlukan bantuan, pengertian dan ksih sayang;

2. Pendekatan yuridis terhadap anak hendaknya lebih mengutamakan pendekatan persuasuf-edukatif dan pendekatan kejiwaan (psikologis) yang berarti sejauh mungkin menghindari proses hukum yang semayamata bersifat menghukum, yang bersifat degradasi mental dan penurunan semangat (discouragement) serta menghindari proses stigmatisasi yang dapat menghambat proses perkembangan, kematangan dan kemandirian anak dalam arti yang wajar.

Atas dasar hal tersebutlah, proses peradilan pidana yang digelar tujuannya bukanlah pada penghukuman, tetapi perbaikan kondisi, pemeliharaan dan perlindungan anak serta pencegahan penanggulangan tindakannya melalui tindakan pengadilan yang konkrit. ${ }^{65}$

Pembaharuan hukum melalui pembaharuan Undang-Undang Narkotika sebagai bagian dari kebijakan kriminal bertujuan agar menjadikan hukum pidana lebih baik dan sesuai dengan nilai yang ada di masyarakat seperti yang dikemukakan oleh Barda Nawawi Arief:66

1. Pembaharuan hukum pidana pada hakikatnya bagian dari upaya untuk mengatasi masalah-masalah sosial (termasuk masalah kemanusiaan) untuk mencapai atau menunjaang tujuan nasional (kesejahteraan masyarakat dan sebagainya);

2. Sebagai bagaian dari kebijakan kriminal, pembaharuan hukum pidana pada hakikatnya bagian dari upaya perlindungan masyarakat (khususnya upaya penanggualangan kejahatan); dan

${ }^{64}$ Koesno Adi, Diversi Tindak Pidana Narkotika Anak, Setara Pess, Semarang, 2014, hlm. 158159.

65 Ibid.

${ }^{66}$ Barda Nawawi Arief, Op.Cit, hlm. 29-30 
3. Sebagai bagian dari kebijakan dari upaya pembaharuan subtansi hukum (legal subtance) dalam rangka lebih mengefektifkan penegakan hukum.

Pembaharuan hukum pidana pada hakikatnya adalah untuk melindungi hakhak masyarakat dengan melakukan tinjauan dan penilaian kembali sosio-politik, sosio-filosofis, sosio-normatif dan subtantif hukum pidana yang dicitacitakan ${ }^{67}$.Berdasarkan adanya faktor-faktor viktimisasi anak penyalah guna narkotika, dan lebih dominannya putusan pidana penjara yang cenderung menyamakan anak sebagai pelaku tindak pidana ketimbang korban tindak pidana.Meskipun faktor viktimisasi anak penyalah guna narkotika jelas terdapat dalam ketiga perkara yang telah penulis paparkan sebelymnya.Maka kebijakan kriminal yang paling mendesak adalah dekriminalisasi terhadap penyalah guna narkotika. Karena menyamakan anak sebagai pelaku dan diberikan sanksi pidana menimbulkan kerugian, yang menurut Made Sadhi Astuti yang dikutip oleh Koesno Adi adalah sebagai berikut:

1. Anak menjadi lebih ahli tentang kejahatan;

2. Anak diberi cap jahat oleh masyarakat yang disebut stigma;

3. Masyarakat menolak kehadiran mantan narapidana anak;

4. Masa depan suram.

Terlebih lagi dalam pemberian pidana berupa pidana penjara terhadap anak penyalah guna narkotika kurang mencerminkan nilai nilai agar sebuah peraturan dapat dinyatakan sebagai hukum.Seperti yang dikemukakan oleh Gustav Radbruc yang dikutip oleh Usman dan Andi Najemi68, bahwa hukum merupakan suatu unsur kebudayaan, maka hukum seharusnya mewujudkan nilai-nilai dalam kehidupan nyata. Ada tiga nilai yang diperlukan untuk sampai pada pengertian hukum, pertama, ialah keadilan dalam arti kesamaan hak untuk setiap orang di depan pengadilan. Kedua, adalah tujuan keadilan atau finalitas, yaitu sesuatu yang menimbulkan kebaikan atau manfaat.Ketiga, adalah nilai kepastian hukum atau legalitas.

Berdasarkan hal tersebut pidana penjara terhadap anak penyalah guna narkotika sangat sedikit manfaatnya, terlebih jika alasannya adalah untuk membina anak lebih baik. Maka penjatuhan pidana penjara terhadapa 12 (dua belas) anak penyalah guna narkotika dari 13 (tiga belas) perkara sangat tidak tepat karena tidak mencerminkan mengedepankan kepentingan terbaik untuk anak, meskipun dalam laporan penelitian oleh Bapas beranggapan telah mengedepankan asas tersebut. Sementara berdasarkan penelitian pidana penjara

${ }^{67}$ Hafrida, "Kebijakan Hukum Pidana Terhadap Pengguna Narkotika Sebagai Korban Bukan Pelaku Tindak Pidana : Studi Lapangan Daerah Jambi”. Padjadjaran Jurnal Ilmu Hukum. Volume 6 Nomor 2, 2016. Retrieved from http:// jurnal. unpad. ac.id /pjih / article /view /9337, hlm. 187

68 Usman, Andi Najemi. "Mediasi Penal di Indonesia: Keadilan, Kemanfaatan, dan Kepastian Hukumnya". Undang: Jurnal Hukum. Volume 1 Nomor 1, 1 Jun 2018. Retrieved from http://u jh.unja.id/index.php/home/article/view /17, hlm. 70 
yang diberikan kepada penyalah guna narkotika bukanlah upaya penanggulangan yang benar terhadap penyalah guna narkotika. ${ }^{69}$ Upaya dekriminalisasi anak penyalah guna narkotika bukan berarti sebagai penghapusan ancaman pidana suatu perbuatan pidana yang semulanya dinyatakan sebagai perbuatan tindak pidana menjadi bukan tindak pidana.

Pada tahun 2005, Badan Pemerintah Pusat Uni Eropa atau European Monitoring Centre for Drugs and Drugs Addiction (EMCDDA) mengeluarkan defenisi dekriminalisasi penyalah guna sebagai berikut: Decriminalisation of drug possession or use as "removal of sanctions under criminal law, with optional use administrative sanctions, such as the application of civil fines or court ordered therapautic responses"70Sedangkan menurut Anang Iskandar, dekriminalisasi penyalah guna narkotika, didefenisikan sebagai perbuatan membeli, memiliki, menggunakan narkotika dalam jumlah tertentu untuk pemakaian sehari digunakan untuk kepentingan diri sendiri, merupakan perbuatan melanggar hukum narkotika; namun apabila perbuatan tersebut telah dilakukan, upaya paksa dan penghukumannya berupa rehabilitasi. ${ }^{71}$

Maka perlu adanya upaya dekriminalisasi agar dapat membedakan antara korban dan pelaku peredaran gelap narkotika, agar anak yang sejatinya adalah korban peredaran gelap narkotika yang menjadi penyalah guna dapat dijauhkan dari upaya pidana penjara yang merampas hak-hak anak dengan upaya keadilan restoratif seperti yang tercantum dalam Undang-Undang Sistem Peradilan Pidana Anak dengan upaya diversi. Atau pun dengan mengedepankan upaya lain yang lebih humanis seperti pemberian rehabilitasi baik medis dan sosial bagi anak penyalah guna narkotika sesuai dengan Undang-Undang Perlindungan Anak adalah langkah yang leboh tepat karena melindungi kepentingan anak.

Sebab dalam Pasal 127 Undang-Undang Narkotika menyatakan bahwa penyalah guna narkotika untuk diri sendiri diancam dengan pidana paling lama yaitu 4 (empat) tahun. Dan bagi anak ancaman pidana di bawah 7 (tujuh) tahun telah sesuai dengan Undang-Undang Sistem Peradilan Pidana Anak yaitu dapat dilakukan diversi dengan melengkapi syarat bahwa anak belum pernah terlibat tindak pidana yang sama sebelumnya ${ }^{72}$. Namun setiap penyalah guna bagi sendiri, selalu diikuti ancaman Pasal 112 dan Pasal 114 Undang-Undang Narkotika, karena penyalah guna tentu memiliki, menguasai serta membeli narkotika untuk digunakan bagi diri sendiri. Dengan kata lain perlu kejelasan mengenai posisi penyalah guna narkotika untuk diri sendiri adalah korban bukanlah pelaku. Hal tersebut berdapak pada proses diversi anak penyalah guna narkotika tidak dapat dilakukan, karena syarat ancaman pidana dibawah 7

${ }^{69}$ Hafrida, "Analisis Putusan Hakim Pengadilan Negeri Jambi terhadap Pengguna/ Pemakai Narkotika dalam Perspektif Penanggulangan Tindak Pidana Narkotika di Kota Jambi." Jurnal Penelitian Universitas Jambi: Seri Humaniora, vol. 16, Nomor 1, 2014. Retrieved from https://www.neliti.com/publications/43461/analisis-putusan-hakimpengadilan-negeri-jambi-terhadap-pengguna-pemakai-narkoti\#cite, hal.66.

70 Anang Iskandar, Penegakan Hukum Narkotika Rehabilitatif Terhadap Penyalah Gunadan Pecandu, Represif terhadap Pengedar, Elex Media Komputindo, Jakarta, 2019, hlm.37

${ }^{71} \mathrm{Ibid}, \mathrm{hlm} .38$

${ }^{72}$ Lihat Pasal 7 Undang-Undang Nomor 11 Tahun 2012 Tentang Sistem Peradilan Pidana Anak 
(tujuh) tahun dianggap tidak terpenuhi oleh Bapas, hal tersebut dapat dilihat dari hasil laporan penelitian yang dilakukan oleh Bapas yang tidak melakukan diversi dari 3 (tiga) putusan yang telah penulis bahas sebelumnya.

Dengan menekankan bahwa anak penyalah guna narkotika tidak dapat dilihat hanya sebagai pelaku tindak pidana, juga sebagai korban.Karena berdasarkan viktimisasi anak penyalah guna narkotika terbukti adanya viktimisasi anak menjadi penyalah guna narkotika dilihat sebab-sebab melakukan tindak pidana, hal tersebut diakibatkan dorongan dari luar diri anak yang lebih dominan ketimbang dorongan dari dalam diri anak sendiri.Pada hakikatnya bertolak pada pemikiran, bahwa kejahatan penyalahgunaan narkotika pada dasarnya dapat dikulifikasikan sebagai crime without victim.Dengan demikian, korban kejahaan penyalahgunaan narkotika adalah pelaku itu sendiri.

Maka perlu urgensi penanggulangan narkotika khususnya pada anak yang sebagai korban peredaran narkotika, yang menjadi penyalah guna narkotika. Penanggulangan tersebut tidaklah sama dengan perlakuan antara pelaku tindak pidana dan korban tindak pidana, apabila dilakukan dengan hukum pidana penjara dirasa kurang tepat. Penanggulangan berupa pidana penjara dirasa tepat apabila diberikan kepada pelaku tindak pidana.Namun bertolak bahwa anak penyalah guna narkotika adalah korban, maka upaya untuk memberikan perlindungan terhadap anak yang menjadi penyalah guna narkotika juga menjadi prioritas.Agar hak-hak anak dapat terlindungi dan tidak menerima dampak negatif akibat pidana penjara.

Mengingat asas kepentingan terbaik untuk anak yang tercantum baik dalam Undang-Undang Sistem Peradilan Pidana Anak, dekriminalisasi perlu dilakukan dengan cara mengedepankan penerapan rehabilitasi pada anak penyalah guna narkotika atau pun lebih mengedepankan penjatuhan pidana berupa pidana peringatan, pidana dengan syarat, pelatihan kerja ataupun pembinaan dalam lembaga. Maka dengan dekriminalisasi anak penyalah guna narkotika perlu dilakukan agar mendorongnya upaya depenalisasi seperti perawatan atau rehabilitasi bagi anak penyalah guna narkotika sebagai upaya penanggulangan yang tepat bagi anak penyalah guna narkotika yang pada dasarnya adalah korban yang memerlukan perlindungan. Hafrida dalam Hukum dan Peradilan menyebutkan: "Settlement of criminal cases that benefit all parties is a new idea at this time. Restorative justice is one model that is considered to be able to fulfill justice, especially for victims of crime that have been neglected".73

Serta dampak yang diinginkan dari pelaksanaan dekriminalisasi penyalah guna narkotika adalah munculnya keinginan masyarakat yang keluarganya terlanjur menjadi penyalah guna rutin atau pencandu dapat secara sukarela dan memenuhi kewajibannya sebagaimana yang diatur dalam Undang-Undang Narkotika untuk melaporkan diri secara sukarela ke Institusi Penerima Wajib

73 Hafrida, Restorative Justice In Juvenile Justice To Formulate Integrated Child Criminal Court, Jurnal Hukum dan Peradilan ISSN: 2303-3274 (p), 2528-1100 (e) Vol. 8, no. 3 (Nov), pp. 439 457, doi: 10.25216/JHP.8.3.2019.439-457, hlm. 447. http:// 114.129 .22.229: 8545/ index .php /jurnalhukumperadilan/article/view/277/0 
Lapor (IPWL) supaya mendapat perawatan dan tehindar dari tuntutan pidana. ${ }^{74 E k s p e k t a s i ~ i n i ~ m e r u p a k a n ~ s e j a l a n ~ d e n g a n ~ d a s a r ~ p e m i k i r a n ~ U n d a n g-~}$ Undang Narkotika yang bertujuan menyelamatkan bangsa Indonesia dari penyalahgunaan dan peredaran gelap narkotika khususnya bagi generasi penerus bangsa serta menjamin pengaturan upaya rehabilitasi medis dan sosial bagi penyalah guna dan pecandu narkotika.

\section{SIMPULAN}

Berdasarkan pembahasan yang telah diuraikan penulis maka dapat disimpulkan sebagai berikut: Faktor viktimisasi anak penyalah guna narkotika di wilayah hukum Pengadilan Negeri Jambi berdasarkan sebab-sebab anak melakukan tindak pidana dikarenakan ketidak mampuan pemerintah dalam penanggulangan kejahatan narkotika dimana anak kemudian menjadi korban dari tindak pidaa tersebut. Selain itu juga dipengaruhi motivasi intrinsik dan ekstrinsik pada diri anak yang saling berkaitan. Yang mana motivasi ekstrinsik seperti faktor keluarga, faktor lingkungan pertemanan, dan faktor pendidikan dan sekolah anak sangat berpengaruh anak menjadi penyalah guna narkotika. Selanjutnya berkaitan dengan kebijakan hukum pidana mengenai viktimisasi anak penyalah guna narkotika dengan memandang anak sebagai korban perlu dilakukan sebagai langkah yang tepat untuk menanggulangi anak yang menjadi penyalah guna narkotika. Karena dengan melihat viktimisasi anak penyalah guna narkotika dapat menjauhkan anak dari dampak negatif pidana dan lebih melindungi hak-hak kesejahteraan anak. Maka dengan dekriminalisasi anak penyalah guna narkotika perlu dilakukan agar mendorongnya upaya depenalisasi seperti perawatan atau rehabilitasi bagi anak penyalah guna narkotika sebagai upaya penanggulangan yang tepat bagi anak penyalah guna narkotika yang pada dasarnya adalah korban yang memerlukan perlindungan.

\section{Daftar Pustaka}

\section{Dokumen Hukum}

Republik Indonesia.Undang-Undang Tentang Narkotika.UU Nomor 35 Tahun 2009.LNRI Tahun 2009 Nomor 143.TLNRI Nomor 5062.

Republik Indonesia.Undang-Undang Tentang Sistem Peradilan Pidana Anak.UU Nomor 11 Tahun 2012.LNRI Tahun 2012 Nomor 153.TLNRI Nomor 5332.

Republik Indonesia.Undang-Undang Perubahan Atas Undang-Undang Nomor 23 Tahun 2002 Tentang Perlindungan Anak.UU Nomor 35 Tahun 2014.LNRI Tahun 2014 Nomor 297.TLNRI Nomor 5606.

\footnotetext{
${ }^{74}$ Lihat Pasal 128 UndangUndang Nomor 35 Tahun 2009 Tentang Narkotika
} 


\section{Buku}

Adi, Koesno. Diversi Tindak Pidana Narkotika Anak,.Setara Pess, Semarang, 2014.

Ali, Mahrus. Dasar-Dasar Hukum Pidana.Sinar Grafika, Yogyakarta. 2011.

Gultom, Maidin. Perlindungan Hukum Terhadap Anak - Dalam Sistem Peradilan Pidana Anak di Indonesia, Rafika Aditama, Bandung, 2014.

Iskandar, Anang. Penegakan Hukum Narkotika Rehabilitatif Terhadap Penyalah Gunadan Pecandu, Represif terhadap Pengedar. Elex Media Komputindo, Jakarta, 2019.

Lamintang, P.A.F dan Theo Lamintang. Hukum Panitensier Indonesia, Sinar Grafika, Jakarta, 2010.

Nasution, Bahder Johan. Metode Penelitian Ilmu Hukum. Mandar Maju, Bandung, 2008.

Nawawi, Barda. Bunga Rampai Kebijakan Hukum Pidana: Perkembangan Penyusunan Konsep KUHP Baru. Edisi Kedua. Kencana, Jakarta, 2008.

Prakoso, Abintoro. Pembaruan Sistem Peradilan Pidana Anak. Laksbang Grafika, Yogyakarta, 2013.

Teguh, Harrys Pratama. Teori dan Praktek Perlindungan Anak dalam Hukum Pidana.Andi Offset, Jakarta, 2018.

Widiarnata, G. Viktimologi Perspektif Korban Dalam Penaggulangan Kejahatan. Cahaya Atma Pustaka, Yogyakarta. 2014.

Yulia, Rena. Viktimologi Perlindungan Hukum Terhadap Korban Kejahatan, Graha Ilmu, Yogyakarta. 2010.

\section{Jurnal/Majalah Ilmiah}

Candra Dewi, A.A Istri Mas. "Perlindungan Hukum Terhadap Korban Penyalahguna Narkotika Dengan Berlakunya Undang-Undang Nomor 35 Tahun 2009." Jurnal Program Studi Magister Ilmu Hukum Universitas Udayana.Volume 1 Nomor1.4 Okt 2012.Retrieved from https://ojs.unud.ac.id /index.php/jmhu /article/ view/1820.

Hafrida, Hafrida, Yulia Monita, dan Elisabeth Siregar. "Pembinaan Narapidana Anak Di Lembaga Pemasyarakatan Anak Sei. Bulu Muara Bulian”, Jurnal Publikasi 
Pendidikan. Volume 5 Nomor 3, September 2015. Retrieved from https://ojs.unm.ac.id/pubpend/article/view/1613.

Hafrida, Hafrida. "Analisis Putusan Hakim Pengadilan Negeri Jambi terhadap Pengguna/ Pemakai Narkotika dalam Perspektif Penanggulangan Tindak Pidana Narkotika di Kota Jambi." Jurnal Penelitian Universitas Jambi: Seri Humaniora, vol. 16, Nomor 1, 2014. Retrieved from https://www.neliti.com/publications/43461/analisis-putusan-hakimpengadilan-negeri-jambi-terhadap-pengguna-pemakai-narkoti\#cite.

- “Kebijakan Hukum Pidana Terhadap Pengguna Narkotika Sebagai Korban Bukan Pelaku Tindak Pidana : Studi Lapangan Daerah Jambi”. Padjadjaran Jurnal Ilmu Hukum. Volume 6 Nomor 2, 2016.Retrieved from http://jurnal.unpad.ac.id/pjih/article/view/9337.

, Restorative Justice In Juvenile Justice To Formulate Integrated Child Criminal Court, Jurnal Hukum dan Peradilan ISSN: 2303-3274 (p), 2528-1100 (e) Vol. 8, no. 3 (Nov), pp. 439 - 457, doi: 10.25216/JHP.8.3.2019.439-457, http://114.129.22.229:8545/index.php/jurnalhukumperadilan/article/view/ $277 / 0$

Usman, Andi Najemi. "Mediasi Penal di Indonesia: Keadilan, Kemanfaatan, dan Kepastian Hukumnya". Undang: Jurnal Hukum. Volume 1 Nomor 1, 1 Jun 2018. Retrieved from http://ujh.unja.id/index.php/home/article/view /17.

Wahyudi, Dheny. "Perlindungan Terhadap Anak Yang Berhadapan Dengan Hukum Melalui Pendekatan Restorative Justice." Jurnal Ilmu Hukum Jambi, vol. 6, Nomor 1, 1 Feb. 2015. Retrived from https://www.neliti.com/publications/43318/perlindungan-terhadap-anakyang-berhadapan-dengan-hukum-melalui-pendekatan-resto\#cite.

\section{Internet}

Mas Zain, Kamus Hukum Online Indonesia, Indonesia Law Dictonary, Diakses pada tangg 11 September 2019 